\title{
COVID-19 dengan Komorbid Tuberkulosis Paru dan Diabetes Melitus
}

\author{
Muthia Faurin ${ }^{1}$, Fauzar ${ }^{2}$, Roza Kurniati ${ }^{2}$, Alexander Kam ${ }^{3}$, Eva Decroli ${ }^{3}$ \\ ${ }^{1}$ Bagian IImu Penyakit Dalam, Fakultas Kedokteran Universitas Andalas/ RSUP Dr. M. Djamil Padang, Indonesia \\ ${ }^{2}$ Subbagian Pulmonologi, Bagian IImu Penyakit Dalam, Fakultas Kedokteran Universitas Andalas/ RSUP Dr. M. Djamil Padang, \\ Indonesia \\ ${ }^{3}$ Subbagian Endokrin Metabolik dan Diabetes, Bagian IImu Penyakit Dalam, Fakultas Kedokteran Universitas Andalas/ RSUP Dr. M. \\ Djamil Padang, Indonesia
}

\section{A B S T R A C T}

Seorang pria berusia 61 tahun dirawat dengan diagnosis COVID19 terkonfirmasi dengan komorbid tuberkulosis paru dan diabetes melitus tipe 2. Pasien diberikan terapi favipiravir, obat antituberkulosis kategori 1, dan insulin. Pasien memberikan respon terapi yang baik dengan perbaikan klinis dan indikator laboratorium yang membaik.

Kata kunci: COVID-19, tuberkulosis paru, diabetes melitus

A 61-year-old man was admitted a confirmed COVID-19 with comorbid pulmonary tuberculosis and type 2 diabetes mellitus. The patient was given favipiravir therapy, category 1 of antituberculosis drug, and insulin therapy. The patient responded well to therapy with improved clinical and laboratory indicators. Key words: COVID-19, pulmonary tuberculosis, diabetes mellitus

\section{Apa yang sudah diketahui tentang topik ini?}

COVID-19 dengan komorbid dapat menyebabkan terjadinya prognosis yang buruk pada pasien.

\section{Apa yang ditambahkan pada studi ini?}

Penanganan COVID-19 dengan komorbid tuberkulosis paru dan diabetes melitus yang tepat akan memberikan respon terapi yang baik.

\section{CORRESPONDING AUTHOR}

Phone: 081374164765

E-mail:drfauzar@yahoo.com

\section{ARTICLE INFORMATION}

Received: April 24 ${ }^{\text {th }}, 2021$

Revised: May $4^{\text {th }}, 2021$

Available online: May $27^{\text {th }}, 2021$

melalui kontak erat. Pemeriksaan diagnostik yang akurat sangat penting untuk COVID-19 dan TB Paru. Pemeriksaan untuk kedua penyakit ini berbeda dan harus dilakukan pada pasien yang memiliki gejala dari penyakit ini. ${ }^{2}$

Infeksi pada pasien diabetes sangat berpengaruh terhadap pengendalian glukosa darah, dan kadar glukosa darah yang tinggi meningkatkan kerentanan atau memperburuk infeksi. Kejadian infeksi lebih sering terjadi pada pasien dengan diabetes akibat munculnya lingkungan hiperglikemik yang dapat meningkatkan virulensi patogen, menurunkan produksi interleukin, menyebabkan terjadinya disfungsi kemotaksis, dan aktivitas fagositik. Hal 
ini dapat menyebabkan terjadinya prognosis yang buruk pada pasien dengan infeksi paru yang juga menderita diabetes melitus. ${ }^{4,5}$ Infeksi SARS-CoV-2 pada pasien dengan diabetes mungkin memicu kondisi stress metabolik yang tinggi, dengan pelepasan horman hiperglikemik yang tinggi juga dapat menyebabkan peningkatan kadar glukosa darah dan variabilitas glukosa abnormal. ${ }^{6}$

\section{Ilustrasi Kasus}

Seorang pria berusia 61 tahun datang dengan keluhan demam sejak 4 hari yang lalu, demam naik turun dirasakan setiap hari, tidak disertai menggigil. Selain itu, pasien juga mengeluhkan batuk sejak 1 bulan yang lalu, batuk berdahak warna putih, tidak disertai darah. Sesak nafas dirasakan sesekali saat batuk. Penurunan berat badan ada, sejak 2 bulan yang lalu, penurunan sekitar $15 \mathrm{~kg}$. Penurunan nafsu makan sejak 3 minggu yang lalu, makan hanya setengah porsi dari biasa, frekuensi 1-2 kali sehari. Sebelumnya nafsu makan pasien biasa bahkan cenderung meningkat dan sering merasa lapar dalam 6 bulan terakhir. Gangguan penciuman disangkal oleh pasien.

Pasien memiliki riwayat menderita diabetes melitus tipe dua (DMT2) sejak 3 bulan yang lalu dan konsumsi metformin 3x500 mg dan glimepiride 1x2 mg. Ayah pasien juga menderita DMT2 namun tidak rutin berobat. Kakak pasien menderita batuk lama tapi tidak diobati sejak 8 bulan yang lalu, pasien kontak beberapa kali namun tidak tinggal serumah. Istri pasien menderita batuk, dan gangguan penciuman sejak 5 hari yang lalu.

Pada pemeriksaan fisik, pasien compos mentis cooperative, tekanan darah 130/80 $\mathrm{mmHg}$, nadi 92 kali/-menit regular, nafas 24 kali/-menit dan suhu $38^{\circ} \mathrm{C}$. Berat badan $58 \mathrm{~kg}$, tinggi badan 169 $\mathrm{cm}$, dan indeks massa tubuh $20,35 \mathrm{~cm} / \mathrm{kg}^{2}$. Tidak ada kelainan pada pemeriksaan fisik kepala, leher, dan kelenjar getah bening.

Pada pemeriksaan fisik paru, tidak tampak kelainan pada inspeksi dan palpasi. Pada perkusi paru kanan, didapatkan redup batas pekak hepar setinggi RIC V kanan. Pada auskultasi paru kanan didapatkan suara nafas bronkovesikuler, rhonki basah halus nyaring di seluruh lapang paru, dan tidak ada wheezing.

Pada pemeriksaan laboratorium, didapatkan kadar hemoglobin 11,3 gr/dl, leukosit
$14.350 / \mathrm{mm}^{3}$, hematokrit $32 \%$, trombosit $283.000 / \mathrm{mm}^{3}$, laju endap darah $55 \mathrm{~mm} / \mathrm{jam}$. Pada hitung jenis didapatkan basofil $0 \%$, eosinofil $2 \%$, neutrofil batang 4\%, neutrofil segmen $73 \%$, limfosit $12 \%$, dan monosit $9 \%$. Kadar gula darah puasa $77 \mathrm{mg} / \mathrm{dl}$, gula darah 2 jam post prandial $136 \mathrm{mg} / \mathrm{dl}$, HbA1c 7,9\%, D-dimer 1.429 ng/ml. Analisis gas darah dalam batas normal. Pasien dilakukan pemeriksaan swab tenggorok dan dengan metode polymerase chain reaction (PCR) didapatkan hasil positif COVID-19.

Pada pemeriksaan radiologi X-ray dada, didapatkan kesan pneumonia bilateral dan kecurigaan tuberkulosis paru. Kemudian dilakukan pemeriksaan tes cepat molekuler dan didapatkan hasil MTB Detected Medium.

Pasien didiagnosis dengan COVID-19 terkonfirmasi dengan derajat sedang, tuberkulosis paru kasus baru terkonfirmasi bakteriologis, dan diabetes melitus tipe 2 tidak terkontrol normoweight. Pasien diterapi dengan diet diabetes 2100 kkal, injeksi ceftriaxone 2x1 gram intravena, n-acetylsistein $3 \times 200 \mathrm{mg}$ per oral, dan paracetamol 3x500mg per oral. Pasien kemudian diterapi dengan favipiravir loading $2 \times 1600 \mathrm{mg}$ per oral hari pertama, dilanjutkan $2 \times 600 \mathrm{mg}$ per oral hari kedua sampai kelima. Azitromicin 1x500 mg, vitamin C 2x500 mg, dan zink 1x20 mg juga dimulai setelah pasien dikonfirmasi menderita COVID-19. Pasien juga diberikan injeksi heparin 2x5000 IU subkutan.

Tatalaksana tuberkulosis paru yang diberikan adalah isoniazid $1 \times 300 \mathrm{mg}$, rifampisin $1 \times 600 \mathrm{mg}$, etambutol $1 \times 1000 \mathrm{mg}$, pirazinamid 1x1250 mg, dan vitamin B 6 1x $25 \mathrm{mg}$. Untuk kontrol gula darah, diberikan injeksi detemir $1 \times 10$ unit subkutan.

Pasien memberikan respon terapi yang baik dengan perbaikan klinis dan indikator laboratorium yang membaik. Tidak ada efek samping terapi yang ditemukan selama perawatan. Setelah dilakukan pemeriksaan swab tenggorok ulang pada hari ke-10 dari swab pertama dan didapatkan hasil negatif COVID-19, pasien diperbolehkan rawat jalan setelah 12 hari rawatan dengan melanjutkan obat antituberkulosis dan insulin di rumah.

\section{Diskusi}

Diagnosis COVID-19 terkonfirmasi pada pasien ditegakkan dari anamnesis, pemeriksaan fisik dan 
pemeriksaan penunjang. Pada pasien ini didapatkan keluhan utama berupa demam sejak 4 hari yang lalu, disertai dengan keluhan batuk dan adanya anggota keluarga yang menderita keluhan yang sama bahkan disertai dengan gejala hilangnya penciuman.

Di era pandemi COVID-19 ini, pasien dengan demam akut $\geq 38^{\circ} \mathrm{C}$ atau terdapat 3 atau lebih gejala dan/atau tanda demam/riwayat demam, batuk, kelelahan, sakit kepala, mialgia, nyeri tenggorokan, pilek, hidung tersumbat, sesak nafas, anoreksia, mual, muntah, diare, penurunan kesadaran dapat dikategorikan sebagai kasus suspek..$^{1,7}$ Oleh karean itu, pada pasien dilakukan pemeriksaan swab PCR dimana pemeriksaan ini merupakan metode yang disarankan utnuk mendiagnosis COVID-19 dan memiliki sensitivitas yang tinggi untuk diagnosis., ${ }^{7,8}$ Pengambil sampel dari swab hidung memiliki nilai positivitas $63 \%$ dan swab faring $32 \%$-sehingga perlu dilakukan keduanya untuk mendiagnosis pasien. ${ }^{6}$ Pada pasien ini didapatkan hasil swab PCR positif dan pasien didiagnosa sebagai COVID-19 terkonfirmasi dengan derajat sedang karena pada pasien ditemukan tanda klinis pneumonia (demam, batuk, sesak) namun tidak ditemukan gejala pneumonia berat.1,8,9

Pada pasien ini diberikan terapi sesuai dengan COVID-19 terkonfirmasi derajat sedang yakni pemberian antivirus favipiravir loading 2x1600 mg hari pertama, dilanjutkan $2 \times 600 \mathrm{mg}$ po hari kedua sampai kelima, azitromicin $1 \times 500 \mathrm{mg}$ po, vitamin $\mathrm{C} 2 \times 500 \mathrm{mg}$ po, zink $1 \times 20 \mathrm{mg}$ po. Pemberian antivirus dan vitamin $\mathrm{C}$ sesuai dengan terapi yang dianjurkan pada pedoman tatalaksana COVID-19 pada derajat sedang. Azitromicin dan ceftriaxon diberikan karena adanya kecurigaan infeksi bakteri yang didukung dengan adanya leukositosis dan nilai hitung jenis shift to the right pada pasien ini. ${ }^{1}$

Pemberian $\mathrm{N}$ acetylsistein pada pasien ini tidak hanya diperlukan sebagai obat batuk mukolitik namun dapat digunakan sebagai antioksidan dikarenakan COVID-19 berhubungan dengan ketidakseimbangan oksidan dan antioksidan yang dapat mengakibatkan inflamasi dan kerusakan jaringan. ${ }^{1}$

Selain itu pada pasien juga didiagnosis sebagai TB paru dimana dari anamnesis, pemeriksaan fisik dan penunjang ditemukan gejala dan tanda yang mendukung diagnosis TB Paru seperti adanya batuk kronis lebih dari 2 minggu, keringat pada malam hari, demam, dan penurunan berat badan. Pasien juga dikenal menderita DMT2 sejak 3 bulan yang lalu. Diabetes melitus merupakan salah satu faktor risiko tersering pada pasien TB paru. Frekuensi DMT2 pada pasien TB dilaporkan sekitar $10-15 \%$ dan prevalensi penyakit ini $2-5$ kali lebih tinggi pada pasien dengan DM dibandingkan non-DM. 4,10

SARS-CoV-2 dapat melewati membran mukosa, terutama mukosa nasal dan laring, kemudian memasuki paru-paru melalui traktus respiratorius. Selanjutnya, virus akan menyerang organ target yang mengekspresikan Angiotensin Converting Enzyme 2 (ACE2), seperti paru-paru, jantung, sistem renal dan traktus gastrointestinal.

Protein S pada SARS-CoV-2 memfasilitasi masuknya virus ke dalam sel target. Masuknya virus bergantung pada kemampuan virus untuk berikatan dengan ACE2, yaitu reseptor membran ekstraselular yang diekspresikan pada sel epitel, dan bergantung pada priming protein $\mathrm{S}$ ke protease selular, yaitu TMPRSS2. Protein $S$ pada SARS-CoV-2 dan SARS-CoV memiliki struktur tiga dimensi yang hampir identik pada domain receptor-binding. Protein $\mathrm{S}$ pada SARS-CoV memiliki afinitas ikatan yang kuat dengan ACE2 pada manusia. Pada analisis lebih lanjut, ditemukan bahwa SARS-CoV-2 memiliki pengenalan yang lebih baik terhadap ACE2 pada manusia dibandingkan dengan SARS-CoV. ${ }^{9}$

Dalam suatu penelitian, ditemukan bahwa paru-paru pasien dengan TB juga menunjukkan ekspresi ACE2 yang tinggi, sehingga ditemukan bahwa infeksi TB dapat meningkatkan resiko SARCov-2 tidak hanya melalui keadaan imunosupresif namun juga melalui peningkatan ekspresi ACE2. Teori ini didukung oleh studi observasi kecil terhadap 46 pasien di Tiongkok. Dalam penelitian tersebut ditemukan bahwa infeksi TB aktif dan laten cenderung menunjukan gejala COVID-19 yang lebih berat serta perkembangan klinis yang lebih cepat dibandingkan pneumonia bakteri dan virus lainnya. ${ }^{3}$

Terdapat peningkatan nilai D-dimer menunjukkan bahwa pasien mengalami hypercoagulable state. Pada infeksi SARS-CoV-2 ini terdapat data yang menunjukan bahwa adanya gangguan koagulasi, kelainan yang paling umum adalah terjadinya peningkatan D-Dimer dan waktu protrombin yang memanjang. Penelitian

Muthia Faurin 
memperlihatkan, pasien yang meninggal memiliki kadar D-Dimer yang jauh lebih tinggi dan waktu protrombin yang lebih panjang dibandingkan dengan pasien yang selamat. ${ }^{1,11}$

Pada DMT2 juga terjadi ketidakseimbangan antara koagulasi dan fibrinolisis dengan peningkatan kadar faktor pembekuan sehingga dapat mendukung terjadinya hiperkoagulasi. Dengan demikian DMT2 dalam hubungannya dengan COVID-19 juga dapat memperburuk kondisi pasien. ${ }^{9}$ Hal ini menyebabkan setiap pasien yang dirawat dengan COVID-19 dianjurkan untuk dilakukan penilaian indikasi pemberian antikoagulan dan tidak terdapat kontraindikasi pemberian antikoagulan. Antikoagulan yang menjadi pilihan adalah enoxaparin atau unfractionated heparin. ${ }^{1}$

Efek samping perdarahan atau komplikasi lain harus dipantau selama permberian antikoagulan. Antikoagulan profilaksis diberikan selama pasien dirawat. Jika kondisi pasien membaik dan dapat imobilisasi aktif serta penilaian ulang tidak terdapat resiko terjadinya trombosis maka antikoagulan dapat dihentikan. ${ }^{1}$

Kemungkinan penyebab meningkatnya infeksi paru seperti COVID-19 dan TB paru pada pasien diabetes berupa defek pada fungsi paru dan mekanisme pertahanan penjamu. Pada penderita hiperglikemia yang lama dapat mengalami gangguan fungsi pada epitel pernafasan, motilitas silia, gangguan fungsi endotel kapilar vaskular paru sehingga dapat menjadi faktor kegagalan pertahanan melawan infeksi. Diabetes dan hiperglikemia yang tidak terkontrol dilaporkan menjadi prediktor yang menyebabkan keparahan dan kematian pada pasien dengan infeksi virus termasuk SARS-Cov-2.3,6

Infeksi pada pasien DMT2 sangat berpengaruh terhadap pengendalian glukosa darah, dan kadar glukosa darah yang tinggi meningkatkan kerentanan atau memperburuk infeksi. Kejadian infeksi lebih sering terjadi pada pasien dengan diabetes akibat munculnya lingkungan hiperglikemik yang dapat meningkatkan virulensi patogen, menurunkan produksi interleukin, menyebabkan terjadinya disfungsi kemotaksis, dan aktivitas fagositik. Hal ini dapat menyebabkan terjadinya prognosis yang buruk pada pasien dengan infeksi paru yang juga menderita DMT2. ${ }^{4,5}$ Infeksi SARS-CoV-2 pada pasien dengan diabetes mungkin memicu kondisi stress metabolik yang tinggi yang kemudian dapat menyebabkan peningkatan kadar glukosa darah dan variabilitas glukosa yang abnormal. ${ }^{6}$

Progresivitas COVID-19 dapat dipercepat dan diperburuk dengan adanya diabetes. Pasien dengan komorbid DMT2 dianjurkan untuk meningkatkan frekuensi pengukuran kadar glukosa darah dan dilakukan penyesuaian dosis bila target glukosa darah tidak tercapai. Dengan demikian, pada pasien ini dianjurkan untuk diberikan insulin untuk kendali glikemik.1,9

Proses pengobatan TB Paru tidak berubah pada pasien dengan atau tanpa COVID-19. Proses pengobatan tetap dilanjutkan tanpa terganggu oleh pengobatan COVID-19. Penderita TB tetap diberikan pengobatan sesuai standar. Namun, perlu diperhatikan pemberian pengobatan COVID19 yang tepat, misalnya dengan tidak memberikan imunosupresif karena dapat menyebabkan reaktivasi infeksi pada TB laten. ${ }^{2}$

\section{Simpulan}

Pasien COVID-19 terkonfirmasi dengan komorbid tuberkulosis paru dan DMT2 yang didiagnosis dan diterapi dengan tepat akan memberikan respon terapi yang baik dengan perbaikan klinis dan indikator laboratorium yang membaik.

\section{Daftar Pustaka}

1. Burhan E, Santoso AD et al. Pedoman Tatalaksana Covid 19 Edisi Kedua. Jakarta : Perhimpunan Dokter Paru Indonesia. 2020

2. Soeroto AY, Santoso P, et al. Review Artikel Khusus Kompendium Diagnostik dan Pengobatan Covid 19 Perhimpunan Respirologi Indonesia (PERPARI). Indonesian Journal Chest, 2020; 17: 27-66

3. Wilkison, RJ. Tuberculosis and Type 2 Dibetes Melitus : An Inflamatory Danger Signal in The Time of Corona Virus Disease. Infection Disease Society of America. 2019: 1-3

4. Soelistijo SA, Lindarto D, et al. Pedoman Pengelolaan dan Pencegahan Diabetes Melitus Tipe 2 Dewasa di Indonesia. Jakarta : PB PERKENI. 2019

5. Purnama SD. Diagnosis dan Klasifikasi Diabetes Melitus pada Buku Ajar Ilmu Penyakit Dalam Edisi VI. Jakarta : Interna Publishing. 2014

6. Hussain A, Bhowmik B, Moreira NC. Covid 19 and Diabetes : Knowledge in Progress. Norway : Diabetes Research and Clinical Practice, 2020: 1-9

7. Handayani I, Rendra HD et al. Penyakit Virus Corona 2019. Jurnal Respirologi Indonesia. 2020; 40: 119-129

8. Gandhi RT, Lynch JB, Carlos del R. Mild or Moderate Covid. The New England Journal of Medicine, 2020; 18; $1757-66$ 
9. Nur Indah F. Tinjauan Pustaka Covid 19 : Virologi, Patogenesis, dan Manifestasi Klinis. Jurnal Medika Malahayti, 2020; 4 : 194-201

10. Keputusan Mentri Kesehatan Indonesia. Pedoman Nasional Pelayanan Kedokteran Tata Laksana Tuberkulosis. Jakarta, 2019

11. Tadjoedin H. Kondisi Hiperkoagulabilitas pada Buku Ajar Ilmu Penyakit Dalam Edisi VI. Jakarta : InternaPublishing, 2014 